\title{
EPIDEMIOLOGIC PROFILE OF SURGERY FOR SPINOMEDULLARY INJURY AT A REFERRAL HOSPITAL IN A COUNTRY TOWN OF BRAZIL
}

\author{
PERFIL EPIDEMIOLÓGICO DA CIRURGIA DE TRAUMA RAQUIMEDULAR EM HOSPITAL \\ DE REFERÊNCIA NO INTERIOR DO BRASIL
}

\author{
PERFIL EPIDEMIOLÓGICO DE CIRUGÍA DE TRAUMA RAQUIMEDULAR EN HOSPITAL \\ DE REFERENCIA EN UNA CIUDAD DEL INTERIOR DE BRAZIL
}

Danilo Magnani Bernardi ${ }^{1}$

\begin{abstract}
Objectives: To analyze the epidemiological profile of patients undergoing surgery at a referral hospital in a small, country town. Methods: A retrospective study was carried out between February 2009 and May 2010, in a Regional Referral unit, with a total of 24 patients. The cases study included all patients undergoing surgery for spinal trauma during this period, with or without neurological deficits. The data analyzed were: sex, age, location and degree of the injury, and mechanism of the injury. Results: The medianage of the patients was 35.8 years, and $75 \%$ were male. The mechanisms of the injury were motorcycle accidents in $37.5 \%$, falls in $33.3 \%$, automobile accidents in $25 \%$, and diving into shallow water in $4.2 \%$. The vertebral level affected was the cervical spine in $44 \%$, the thoracic spine in $36 \%$, and the thoracolumbar level in $20 \%$. The neurological damage, classified according ASIA (American Spinal Injury Association) was complete, or category $\mathrm{A}$ in $37.5 \%$, incomplete, or category B in $4.2 \%$, incomplete, or category C in $12.5 \%$, incomplete, or category D in $8.3 \%$, and incomplete, or category $\mathrm{E}$ in $37.5 \%$. In terms of access route, $64 \%$ of the procedures were performed with posterior access and $36 \%$ with anterior access. Conclusion: The epidemiological profile maintains the trend towards a prevalence of injuries among young men, affecting the cervical level, with the presence of spinal cord lesion. However, accidents involving motorcycles and fallings from heights are factors that can be modified by safety measures on the roads and in the workplace, which can reverse the high prevalence of these accidents.
\end{abstract}

Keywords: Spinal cord injuries; Wounds and injuries; Accidents; Spinal injuries/epidemiology; Spine.

\begin{abstract}
RESUMO
Objetivos: Analisar o perfil epidemiológico desses pacientes tratados cirurgicamente em um hospital de referência do interior. Métodos: Revisão retrospectiva entre fevereiro de 2009 e maio de 2010 em unidade de referência regional, totalizando 24 pacientes. Incluíram-se na casuística todos os pacientes submetidos à cirurgia nesse período, em razão de trauma na coluna vertebral com ou sem déficits neurológicos. Os dados analisados foram sexo, idade, localização e grau da lesão e mecanismo do trauma. Resultados: A média de idade dos pacientes foi 35,8 anos, sendo $75 \%$ do sexo masculino. O mecanismo do trauma distribuiu-se da seguinte maneira: 37,5\% por acidentes com motocicletas, 33,3\% decorrentes de quedas, $25 \%$ por acidentes com automóveis e 4,2\% envolvendo mergulho em águas rasas. Os níveis vertebrais afetados foram coluna cenvical (44\%), coluna torácica (36\%) e região toracolombar (20\%). O comprometimento neurológico, segundo a Classificação ASIA (American Spinal Injury Association), foi lesão completa ou A em 37,5\%, lesão incompleta B em 4,2\%, lesão incompleta C em $12,5 \%$, lesão incompleta $D$ em 8,3\% e, ainda, 37,5\% das lesões foram classificadas como incompletas E. Sessenta e quatro por cento das intervenções realizadas foram por acesso posterior e 36\%, por acesso anterior. Conclusão: O perfil epidemiológico mantém a tendência de predominância de envolvimento de jovens do sexo masculino, de lesões no nível cervical e de ocorrência de lesão medular. Contudo, os acidentes envolvendo motocicletas e quedas de altura são fatores modificáveis por medidas de segurança no trânsito e no trabalho, que podem alterar a elevação de sua prevalência.
\end{abstract}

Descritores: Traumatismos da medula espinal; Ferimentos e lesões; Acidentes; Traumatismos da coluna vertebral/epidemiologia; Coluna vertebral.

\section{RESUMEN}

Objetivos: Analizar el perfil epidemiológico de los pacientes tratados quirúrgicamente en un hospital de referencia en el interior. Métodos: Revisión retrospectiva entre febrero de 2009 y mayo de 2010 en una unidad de referencia regional, con un total de 24 pacientes. Se incluyeron en la casuística a todos los pacientes sometidos a cirugía durante este período, debido a un traumatismo en la columna vertebral con o sin déficit neurológico. Los datos analizados fueron sexo, edad, localización y grado de la lesión y mecanismo del trauma. Resultados: La edad media de los pacientes era de 35,8 años, siendo el 75\% del sexo masculino. El mecanismo de trauma se distribuyó de la siguiente manera: $37,5 \%$ de accidentes de motocicleta, 33,3\% relacionados con caídas, 25\% de accidentes con automóviles y 4,2\% debidos a buceo en aguas poco profundas. Los niveles vertebrales afectados fueron columna cervical (44\%), columna torácica (36\%) y región toracolumbar (20\%). El deterioro neurológico, de acuerdo con la Clasificación ASIA (American Spinal Injury Association) fue lesión completa o A en el 37,5\% de los pacientes, lesiones incompletas B en 4,2\%, lesión incompleta C en 12,5\%, lesión incompleta D en $8,3 \%$ y $37,5 \%$ de las lesiones se clasificaron como incompletas E. Sesenta y cuatro por ciento de las intervenciones se realizaron por vía posterior y $36 \%$ para vía anterior. Conclusión: El perfil epidemiológico mantiene la tendencia del predominio de varones jóvenes, de las lesiones a nivel cervical y la presencia de lesiones de la médula espinal. Sin embargo, los accidentes de motocicleta y las caídas de altura son factores modificables por medidas de seguridad en el tránsito y en el trabajo, lo que puede cambiar la elevación de su prevalencia.

Descriptores: Traumatismos de la médula espinal; Heridas y traumatismos; Accidentes; Traumatismos vertebrales/epidemiologia; Columna vertebral.

1. Hospital Regional do Noroeste, Paranavaí, PR, Brazil.

Study conducted at the Hospital Regional do Noroeste, Paranavaí, PR, Brazil.

Correspondence: Rua do Bosque, 4500 - Jardim Social, Umuarama, PR, Brazil. 87506-010. neuroumuarama@gmail.com

Received on 03/30/2012, accepted on 12/17/2012 


\section{INTRODUCTION}

Spinomedullary injury is defined as damage to the spinal cord resulting in changes in the motor, sensory, or autonomic functions that may be temporary or permanent. ${ }^{1}$ It is a growing public health issue, mainly due to the profile of the population affected (economically active young adults) and the severity of their injuries. Closely linked historically to traffic and urban violence, its real socioeconomic impact is not yet well characterized on a national level. Because there is no mandatory notification procedure, Brazil still does not have accurate figures, and the estimates are indirect and influenced by isolated case series, especially in the big cities. Even so, when compared to those in the international literature, the rates are alarming and the data are significant. ${ }^{1-5}$ The objective of this study was to analyze the epidemiological profile of patients who underwent surgical treatment in a referral hospital far from the major centers.

\section{METHODS}

A retrospective review of medical care from February 2009 to May 2010 in a regional neurosurgery referral unit serving 29 municipalities, corresponding to approximately 270,000 inhabitants (according to the 2009 IBGE [Brazilian Institute of Geography and Statistics] estimate) with a hospital center located in the main municipality, with a population of 83,000 , totaling 24 patients. All the patients who underwent surgery for spinal trauma with or without neurological deficits during this period were included in the case series. The data analyzed were sex, age, location and level of injury, mechanism of trauma, and surgical access approach.

\section{RESULTS}

The average age of the patients was 35.8 years of age, and $75 \%$ were males. The distribution of injuries by trauma mechanism is described in Figure 1. Data related to the vertebral level affected are shown in Figure 2. The neurological involvement resulting from the injuries was classified according to the American Spinal Injury Association (ASIA) classification system, and is shown in Figure 3. The estimated incidence was 71.1 surgical cases per million per year, and the distribution of surgical intervention access approaches is shown in Figure 4. There were no referrals to other centers.

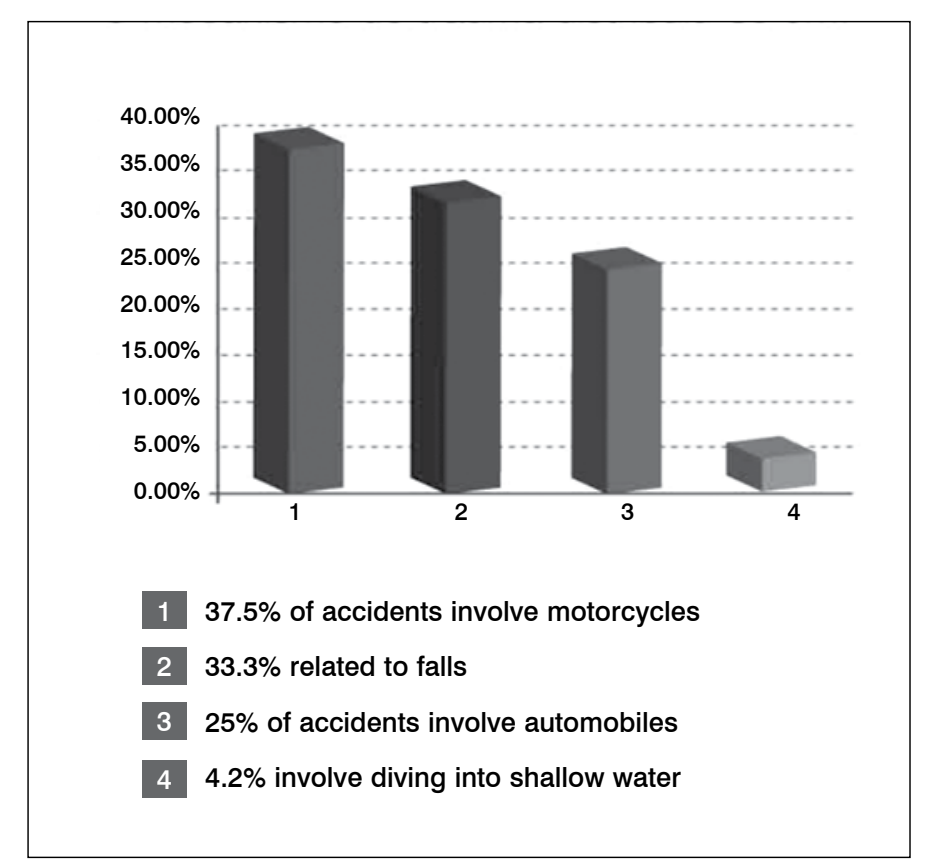

Figure 1. Distribution of the trauma mechanism.

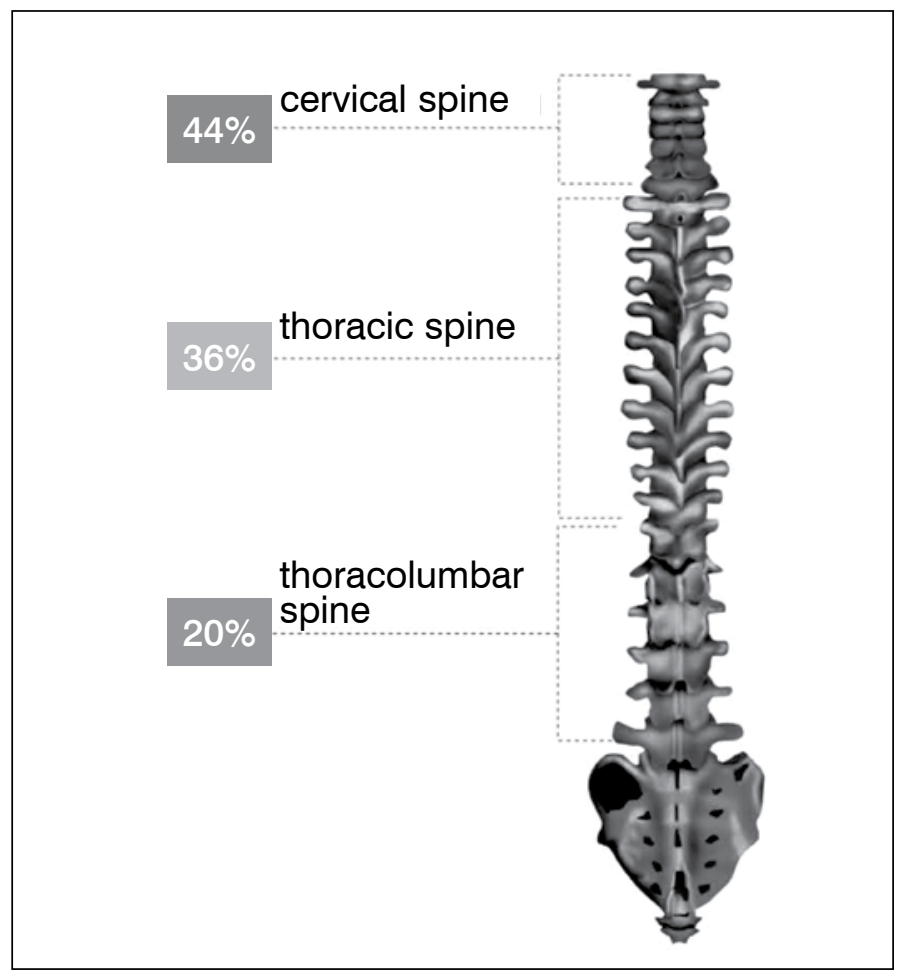

Figure 2. Distribution of the vertebral level affected.

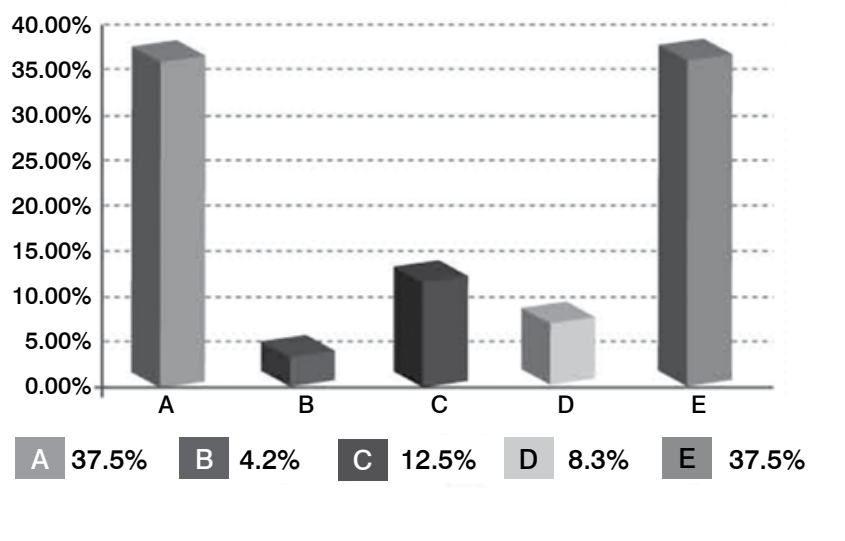

Figure 3. Neurological involvement according to the ASIA (American Spinal Injury Association) classification.

\section{DISCUSSION}

Considered to be a public health problem even in developed countries, the approximate incidence in the United States in 2009 was 40 cases per million inhabitants per year. The profile of involvement of young males, the high social cost created by this most affected economically active sector of the population, and the significant costs associated with rehabilitation and complications are common to studies on spinomedullary injury. ${ }^{1,6-9}$ However, most studies differ as to the etiology of the injuries. Data from the United States emphasize traffic accidents, falls, sports accidents, and violence. ${ }^{1,9}$ Violence historically has a significant incidence in Brazilian urban centers. ${ }^{10}$ However, information from smaller centers shows a higher percentage of traffic accidents as the causal agent, surpassing violence. ${ }^{11}$ Analyzing the causes related to traffic accidents, we did not find significant references related to spinal cord injury, but the sharp rise in the number of motorcycles in the 


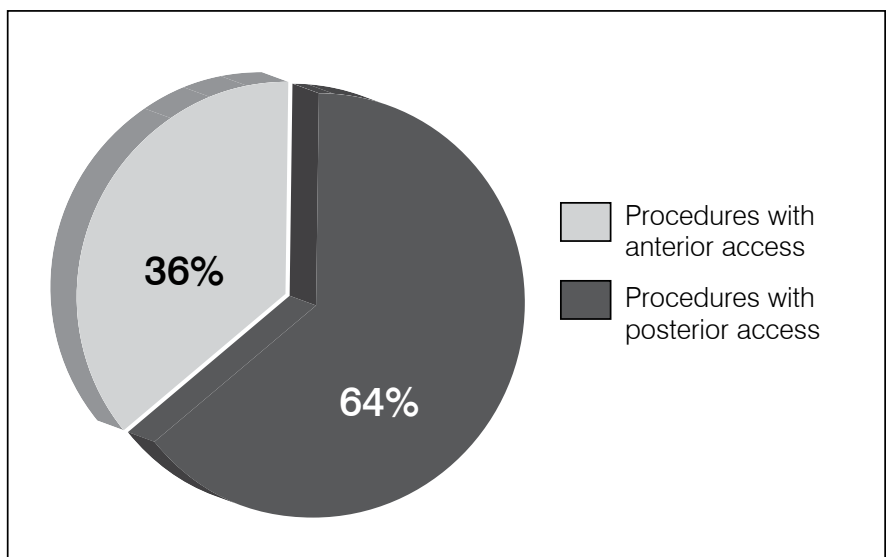

Figure 4. Distribution by access approach of the surgical interventions performed.

streets has been gaining prominence in the Brazilian statistics, corresponding with our data. The 2008 annual statistical report of the Department of Transportation of the State of Paraná shows that $36.53 \%$ of all traffic injuries involved motorcycles, and these numbers are growing as the number of motorcycles increases. ${ }^{12}$ A large percentage of falls from heights has been correlated to workplace safety issues. ${ }^{8}$ Civil construction in Brazil employs more than 10 million people. In 2009, there were almost one million new job openings and a growth forecast for the sector of $6 \%$ annually. ${ }^{13}$ Alongside these levels, there is a greater lack of preparation of workers and greater exposure to risks. In terms of the level of injuries, most studies in the literature cite the cervical spine as the portion most often affected. A-grade or total injuries on the ASIA Classification scale are the most prevalent in the publications. ${ }^{1,14,15}$ No comparative bibliography was found on the subject of surgical access approaches.

\section{CONCLUSION}

The epidemiological profile is consistent with the known trend of involvement of young males, at the cervical level, with the presence of spinal cord injury. The strong prevalence of accidents involving motorcycles and falls from heights suggests a change in the panorama of the majority of surveys conducted on the subject. Both are potentially changeable with the intensification of preventative measures, such as driver education and the reinforcement of workplace safety policies, in the sectors identified.

All authors declare no potential conflict of interest concerning this article.

\section{REFERENCES}

1. Dawodu ST, Klein MJ, Talavera F, Salcido R, Allen KL, Campagnolo DI. Spinal Cord Injury - Definition, Epidemiology, Pathophysiology [Internet]. 2011 [cited 2011 nov 10]. Available from: http://emedicine.medscape.com/article/322480-overview\#showall.

2. Brito LMO, Chein MBC, Marinho SC, Duarte TB. Avaliação epidemiológica dos pacientes vítimas de traumatismo raquimedular. Rev Col Bras Cir. 2011;38(5):304-9.

3. Vasconcelos, ECL, Riberto M. Caracterização clínica e das situações de fratura da coluna vertebral no município de Ribeirão Preto, propostas para um programa de prevenção do trauma raquimedular. Coluna/Columna. 2011;10(1):40-3.

4. Bortoletto $\mathrm{A}$, Matsumoto $\mathrm{MH}$. Epidemiologia das fraturas toracolombares cirúrgicas na zona leste de São Paulo. Coluna/Columna. 2010;9(2):132-7.

5. Custódio NRO, Carneiro MR, Feres CC, Lima GHS, Jubé MRR, Watanabe LE, et al. Lesão medular no Centro de Reabilitação e Readaptação Dr. Henrique Santillo (CRERGO). Coluna/Columna. 2009;8(3):265-8.

6. Souza Júnior MF, Bastos BPR, Jallageas DN, Medeiros AAA. Perfil epidemiológico de 80 pacientes com traumatismo raquimedular, internados no Hospital do Pronto: Socorro Municipal de Belém, PA, no período de janeiro a setembro de 2002. J Bras Neurocir. 2002;13(3):92-8

7. Pirouzmand.F. Epidemiological trends of spine and spinal cord injuries in the largest $\mathrm{Ca}$ nadian adult trauma center from 1986 to 2006. J Neurosurg Spine. 2010; 12:131-140.

8. Campos MF, Ribeiro AT, Listik S, Pereira CAB, Andrade Sobrinho J, Rapoport A. Epidemio- logia do traumatismo da coluna vertebral. Rev Col Bras Cir. 2008;35(2):88-93.

9. National Spinal Cord Injury Statistical Center (NSCISC). Annual Statistical Reports. Annual Report for the Model Spinal Cord Injuri Care Systems. Birmingham: Alabama; 2007.

10. Blanes L, Lourenço L, Carmagnani MIS, Ferreira LM. Clinical and socio-Demographiccharacteristics of persons with traumaticparaplegia living in São Paulo, Brazil. Arq Neuropsiquiatr. 2009;67(2-B):388-90

11. Citadini JM, Scholtão J, Souza RB, Garanhani MR. Perfil epidemiológico dos pacientes com lesão medular do ambulatório de fisioterapia neurológica do Hospital Universitário Regional do Norte do Paraná. Rev Espaço Saúde Londrina. 2003:5(1):48-59.

12. Departamento de Trânsito do Paraná (DETRAN/PR). Estatísticas de Trânsito.In: Anuário Estatístico 2008. Curitiba: Departamento de Trânsito do Paraná; 2008.

13. Câmara Brasileira da Insdústrica da Construção - CEBIC. Construção Civil: análise e perspectivas [Internet]. Banco de dados da CEBIC. Brasília dez 2010. Disponível em: http:// www.cbicdados.com.br/files/textos/063.pdf.

14. American Spinal Injury Association (ASIA). International Standards for Neurological Classifications of Spinal Cord Injury. revised ed. Chicago, IL: American Spinal Injury Association; 2000

15. Kattail D, Furlan JC, Fehlings MG. Epidemiology and clinical outcomes of acute spine trauma and spinal cord injury: experience from a specialized spine trauma center in Canada in comparison with a large national registry. J Trauma. 2009;67(5):936-43. 